\title{
NEONATAL SEIZURES
}

\section{THE OVERLAP BETWEEN DIAGNOSIS OF METABOLIC DISORDERS AND STRUCTURAL ABNORMALITIES}

\section{Case report}

\author{
Alessandra Freitas ${ }^{1,2}$, Erasmo B. Casella², Marcelo Valente ${ }^{2,3}$, \\ Carlos A Buchpiguel ${ }^{4}$, Kette D.R. Valente ${ }^{1}$
}

\begin{abstract}
Inborn metabolic errors (IME) and cortical developmental malformations are uncommon etiologies of neonatal seizures, however they may represent treatable causes of refractory epilepsy and for this reason must be considered as possible etiological factors. This case report aims to demonstrate the importance of neuroimaging studies in one patient with neonatal seizures, even when there are clues pointing to a metabolic disorder. Case report: A previously healthy 14 day-old child started presenting reiterated focal motor seizures (FMS) which evolved to status epilepticus. Exams showed high serum levels of ammonia and no other abnormalities. A metabolic investigation was conducted with normal results. During follow-up, the patient presented developmental delay and left side hemiparesia. Seizures remained controlled with anti-epileptic drugs for four months, followed by relapse with repetitive FMS on the left side. Temporary improvement was obtained with anti-epileptic drug adjustment. At the age of 6 months, during a new episode of status epilepticus, high ammonia levels were detected. Other metabolic exams remained normal. The child was referred to a video-electroencephalographic monitoring and continuous epileptiform discharges were recorded over the right parasagittal and midline regions, with predominance over the posterior quadrant. A new neuroimaging study was performed and displayed a malformation of cortical development. Our case illustrates that because newborns are prone to present metabolic disarrangement, an unbalance such as hyperammonemia may be a consequence of acute events and conduct to a misdiagnosis of IME.
\end{abstract}

KEY WORDS: metabolic disorder, cortical dysplasia, neonatal seizures.

\section{Crises neonatais: a sobreposição entre o diagnóstico das doenças metabólicas e as anormalidades estruturais. Relato de caso}

\begin{abstract}
RESUMO - Erros inatos do metabolismo (EIM) e distúrbios do desenvolvimento cortical são causas pouco comuns de crises neonatais, entretanto eles podem representar causas tratáveis de epilepsia refratária e, por esta razão, devem ser consideradas como possíveis fatores etiológicos. Este relato de caso tem como objetivo demonstrar a importância dos estudos de neuroimagem em um paciente com crises neonatais, mesmo quando as pistas diagnósticas são sugestivas de uma doença metabólica. Relato do caso: Uma criança , previamente hígida, de 14 dias de vida começou a apresentar crises focais motoras (CFM) reiteradas que evoluíram para estado de mal. Os exames demonstraram altos níveis séricos de amônia e nenhuma outra anormalidade. Uma investigação metabólica foi conduzida com resultados normais. Durante a evolução, a paciente apresentou atraso de desenvolvimento neuropsicomotor e hemiparesia no dimídio esquerdo. As crises epilépticas permaneceram controladas com drogas anti-epilépticas durante quatro meses, seguidas de recorrência com CFM reiteradas no hemicorpo esquerdo. Uma melhora temporária foi obtida com o ajuste das drogas anti-epilépticas. Aos 6 meses de vida, durante um novo episódio de estado de mal, níveis de amônia elevados foram novamente detectados. Outros exames metabólicos foram normais. A criança foi encaminhada a monitorização V-EEG e paroxismos epileptiformes contínuos foram registrados na região parassagital e na linha média, com predomínio posterior. Uma nova RM foi realizada e mostrou uma displasia cortical no quadrante posterior direito. Nosso caso ilustra a predisposição que os neonatos têm a distúrbios metabólicos, tal como a hiperamonemia que pode ser conseqüência de eventos agudos, conduzindo ao diagnóstico errôneo de EIM.
\end{abstract}

PALAVRAS-CHAVE: distúrbios metabólicos, displasia cortical, crises neonatais.

\footnotetext{
'Laboratory of Clinical Neurophysiology, Institute and Department of Psychiatry University of São Paulo Medical School, São Paulo SP, Brazil (FMUSP); ${ }^{2}$ Children's Institute, Department of Pediatrics, FMUSP; ${ }^{3}$ Institute and Department of Radiology, FMUSP; ${ }^{4}$ Institute and Department of Nuclear Medicine, FMUSP.
}

Received 3 September 2002, received in final form 15 January 2003. Accepted 22 January 2003.

Dra. Alessandra Freitas - Rua Jesuíno Arruda 901/51 - 04532-082 São Paulo SP - Brasil. FAX: 1130795493.

E-mail: alessandra_freitas@msn.com 
Epileptic seizures in the newborn are a frequent consequence of different encephalopathies, either primary or secondary. Main causes of seizures in this age group are hypoxic-ischemic insults, infections, vascular disease, metabolic diseases, malformations of cortical development, trauma, and some epileptic syndromes (including familial forms) ${ }^{1,2}$. Metabolic encephalopathies encompass metabolic unbalances and inborn metabolic errors (IME). Metabolic unbalances are a common cause of seizures with favorable outcome. On other hand, IME are uncommon etiologies of refractory epilepsy in the neonatal period. However, although many disorders are treatable and successful outcome will depend on rapid diagnosis and early therapy, the IME must be kept in mind $^{3}$. Malformations of cortical development (MCD) are a rare cause of neonatal seizures ${ }^{4}$. Advances in neuroimaging studies have helped to detect these abnormalities and, consequently, to elucidate some of these cases, which had remained previously under or misdiagnosed ${ }^{5}$.

This case report aims to describe the importance of neuroimaging studies in patients presenting neonatal seizures, even when diagnostic clues led to the clinical hypothesis of a metabolic disorder.

\section{CASE}

We present the case of a female, 4 month-old child, with history of non-complicated pregnancy and delivery from healthy and young non-consanguineous parents. Family history for neurological disorders was negative. The mother had a previous history of miscarriages and had an older normal 5 year-old son. At the age of 14 days the patient presented recurring focal motor seizures, involving superior limbs and face, which evolved to a status epilepticus (SE). She was admitted to an Intensive Care Unity (ICU) and during hospitalization, laboratory screening did not reveal any abnormalities, except for high serum levels of ammonia (540mg/dl; normal ranges: 20-50). A neuroimaging study (MRI) performed on that occasion was normal. EEG showed slowing of background activity, mainly over the right hemisphere, but its result was not taken into account, since this study had been performed soon after treatment for SE with Thiopental IV. The patient was released with phenobarbital and clobazam. The clinical suspicion of an IME, due to hyperammonemia, and knowledge of its devastating consequences, drove the investigation towards a metabolic screening. At that time, neurological examination showed severe global hypotonia with consequent developmental delay; however no focal deficits were detected. A complete metabolic investigation was conducted according to the guidelines of Chakrapani et al. ${ }^{2}$ which included: serum levels of glucose, calcium, magnesium, electrolytes, ammonia, urea, lactate, pyruvate, biotinidase; urinary and plasmatic amino acids and organoacids; anion gap, blood gases, liver function tests, and urine test (ketonuria).

The patient remained seizure-free until the age of four months, when she started presenting brief focal seizures on the left side. We observed a focal neurological deficit on the left body, which had been interpreted by her mother as seizure-related or as a post-ictal phenomenon. An increase of AED dosage rendered the patient once more seizure-free, but the deficit persisted without improvement. She was referred to an EEG study that disclosed continuous epileptiform discharges over the right with posterior quadrant, progressing to the entire right hemisphere during seizures (Fig 2). Taking into account these findings,

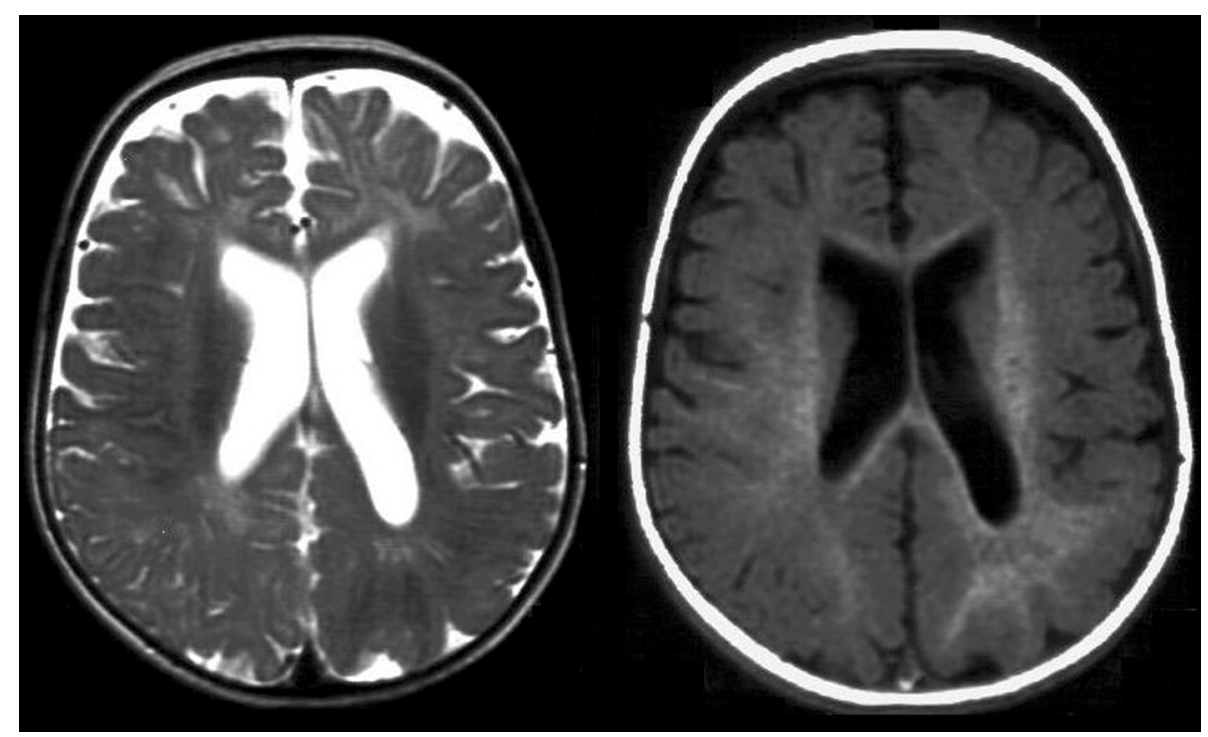

Fig 1. MR image at 4 months. A large area of cortical thickening over the right posterior quadrant in $T 1$ with hyperintense signal in $T 2$ is observed. 


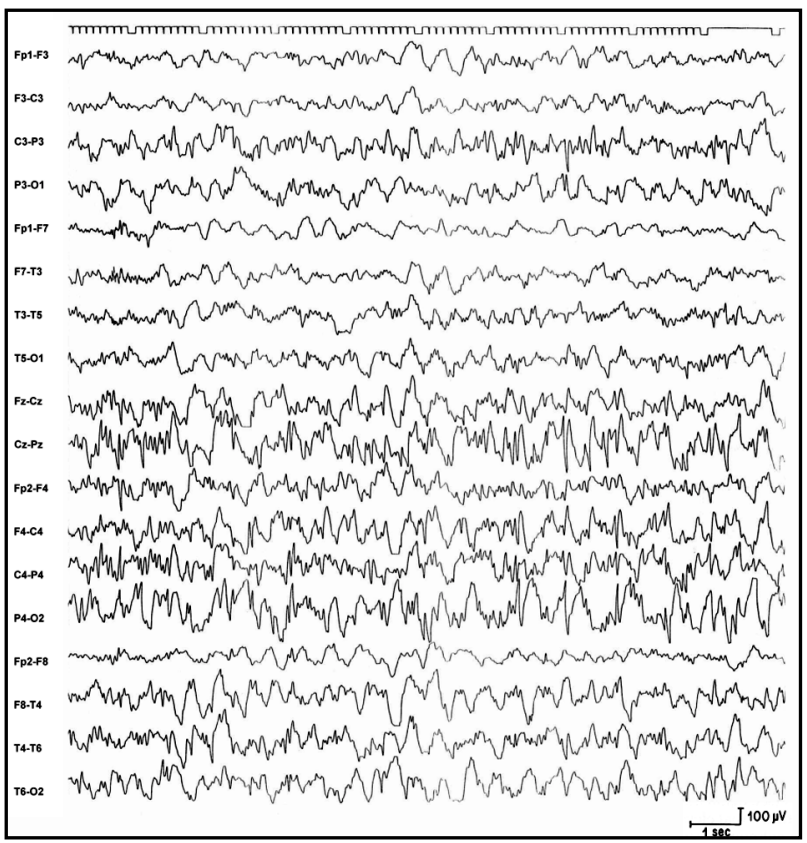

Fig 2. Continuous epileptiform discharges over the right parasagittal region involving the midline. No concomitant clinical event was recorded.

a new MRI was conducted and an area of cortical dysplasia was observed on the right parieto-occipital region (Fig 1). Meanwhile, a sudden cognitive decline was referred by the mother, who then brought the patient to the hospital. An immediate V-EEG study was conducted and revealed SE characterized by episodes of subtle bilateral blinking, motionlessness and impairment of consciousness, which were finally controlled, with IV Thiopental. The epileptic seizures originated on the right posterior quadrant, an observation corroborated by ictal SPECT studies, which revealed a hyperperfusion on this region (Fig 3). During her latest admission at the ICU, metabolic screening revealed once more high ammonia levels, as opposed to a previous outpatient investigation. After stabilization of SE, normal ammonia levels were obtained, demonstrating that this metabolic unbalance was a consequence of a stress factor, in this case SE.

\section{DISCUSSION}

Seizures may be the most frequent and often the only clinical sign of central nervous system (CNS) dysfunction in the neonate ${ }^{6}$. The occurrence of seizures prompts urgent medical attention in this phase, and several disorders that occur frequently may cause brain dysfunction ${ }^{7,8}$. The findings of Koch et al. ${ }^{9}$ raised the possibility that metabolic disease may cause a disruption of normal myelin development, as a result, a clinical investigation for an early intervention is mandatory in order to prevent damages. The common clinical profile in metabolic encephalopathy is that apparently healthy newborns, will develop non-specific symptoms such as lethargy, poor feeding, vomiting, or irritability after a symptom-free period. Metabolic acidosis, altered sensorium, convulsions, and hyperammonaemic coma become apparent soon afterwards. These features must raise the clinical suspicion of a metabolic disorder and consequently mandate a detailed metabolic investigation ${ }^{3,10}$.

In our case, high ammonia concentrations warranted a thorough investigation for metabolic etiology. The main causes of hyperammonia are organic acidaemias (propionic, methylmalonic, and isovaleric acidaemia) and urea-cycle defects which classically

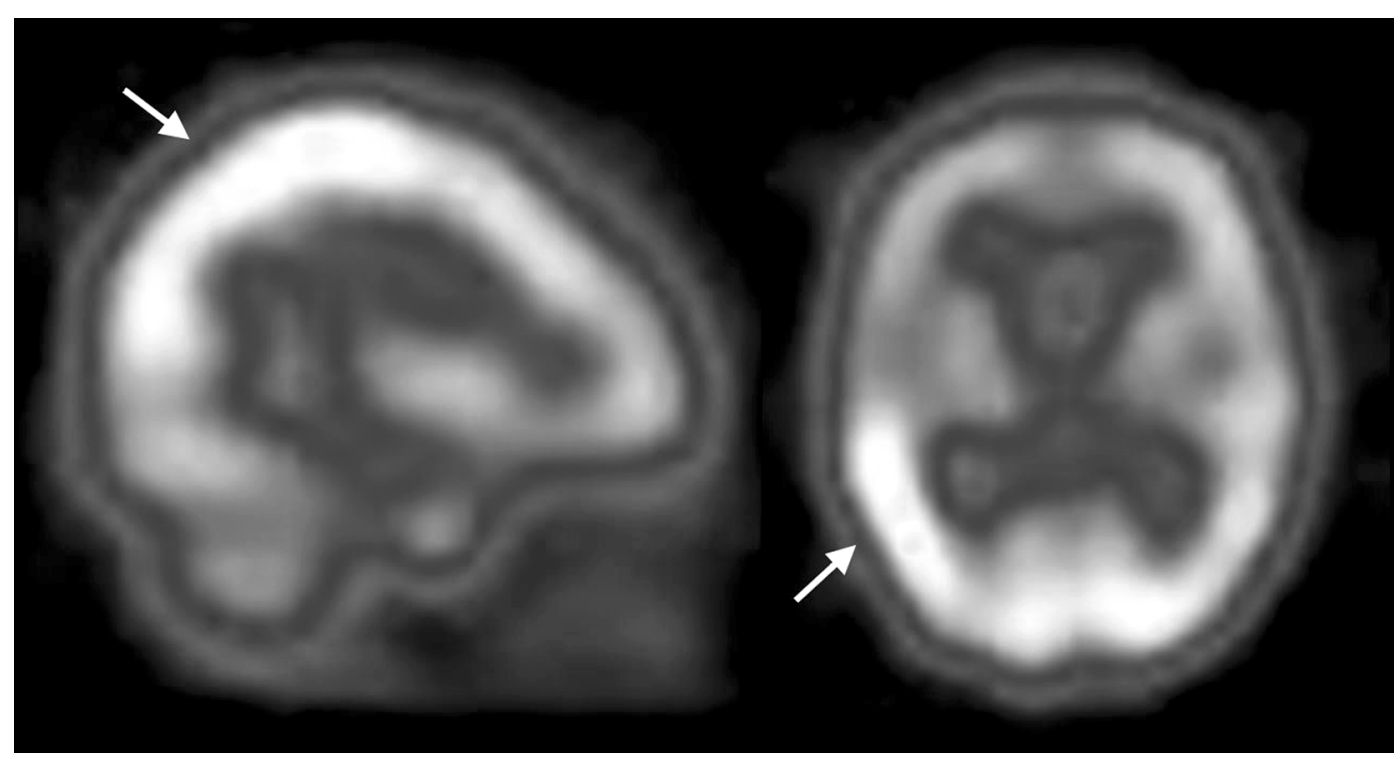

Fig 3. Ictal SPECT study demonstrating a region over hyperperfusion on axial and sagital views. 
present themselves in this manner, and in either case, respiratory alkalosis may be the initial acid-base disturbance. The likelihood of a metabolic disorder is very high in the presence of ketonuria, as neonates otherwise do not readily produce ketones ${ }^{3,6}$.

Although high ammonia levels will guide to a search for a IME, it must be emphasized that hyperammonemia may occur in many situations in the newborn period, including prematurity, sepsis, and other nonspecific liver dysfunction, viral infections and intoxications ${ }^{6}$. Our case illustrates hyperammonemia as a consequence of acute seizure, since blood samples were drawn when the patient was on intensive care and at an unstable and severe clinical conditions. It is important to emphasize that, when suspecting an IME, diagnostic investigation must prioritize these diseases, since they may have a fatal outcome and may be controlled easily with dietary restriction and supplementation of specific factors ${ }^{9}$. This is the reason why, in our case, investigation was conducted towards one of these diagnoses, which was then promptly discarded.

In our study, a normal metabolic investigation associated with refractory epilepsy and onset of focal neurological deficits led to a new neurophysiological and neuroimaging investigation. Surface EEGs identified the presence of focal rhythmic sharp-wave discharges, lasting from several seconds to almost continuous, a pattern reported as suggestive of cortical dysplasia ${ }^{11,12}$. In this case, MRI showed cortical thickening associated with a less complex gyration of the right parieto-occipital region, possibly with an extension to the temporal lobe. Myelination was asymmetrical, but accelerated in the regions mentioned above. These findings were suggestive of focal cortical dysplasia (FCD).

The presence of a previous normal MRI performed at the age of 14 days only illustrates the fact that in newborns the white matter remains relatively low in attenuation compared to the gray matter ${ }^{13}$. This probably results from the white matter content of the newborn brain and the lack of myelination in this phase, especially in frontal and parieto-occipital cortex, which may guide to false negative results and as a consequence, malformations of cortical development may not be diagnosed.

Since developmental defects are responsible for only $5-10 \%$ of neonatal seizures and FCD is rarely clinically manifest during the neonatal period ${ }^{1}$, it was not the main hypothesis in this case.
We believe it is important to emphasize that a presence of a metabolic disorder does not exclude a MCD. Although this is uncommon, it has been demonstrated in a variety of disorders, such as Zellweger syndrome and its association with cortical dysplasia ${ }^{4}$. In a recent review, Porter et al. ${ }^{14}$ pointed out high prevalence of metabolic disorder in patients with heterotopias. In the imminence of epileptic seizures during the neonatal period, a detailed investigation must be rapidly carried out, due to its severity and to the fact that prognosis depends on etiology and early treatment. Although laboratory exams are a priority, the hypothesis of a metabolic disease does not preclude imaging studies.

In conclusion, in this case report we would like to highlight that: 1. Newborns and infants are prone to present metabolic unbalances, and a finding such as hyperammonaemia may be seen as the cause for seizures instead of its consequence, which may lead to a misdiagnosis of an IME; 2 . MRI studies during the neonatal period may disclose false-negative results and therefore evolutionary studies are essential. It is important to emphasize that the diagnosis of an IME does not rule out malformations of cortical development.

\section{REFERENCES}

1. Volpe JJ. Neonatal Seizures. In Volpe JJ (ed). Neurology of the newborn 4.Ed. Wien: W.B. Saunders 2000;178-217.

2. Tharp BR. Neonatal seizures and syndromes. Epilepsia 2002;43 (Suppl.3):2-10.

3. Chakrapani A, Cleary MA, Wraith JE. Detection of inborn errors of metabolism in the newborn. Arch Dis Childh 2001 May; 84:F205-F210.

4. Sansaricq C, Lyon G, Kolodny EH. Seizures in hereditary metabolic disease: evaluation of suspected hereditary metabolic disease in the etiology of seizures. In Kotagal P, Luders HO (eds). The epilepsies: etiologies and prevention. Cleveland: Academic Press, 1999:479-490.

5. Palmini A. Disorders of cortical development. Curr Opinion Neurol 2000;13:183-192.

6. Kahler SG. Neonatal metabolic disorders. In Kotagal P, Luders HO (eds). The epilepsies: etiologies and prevention. Cleveland: Academic Press, 1999:479-490.

7. Mizrahi EM, Kellaway P. Characterization and classification of neonatal seizures. Neurology 1987;37:1837-1844.

8. Rocha C, Gonfinetti N, Pelluci L, Rocha MSG. Hipocalcemia e crises neonatais. Arq Neuropsiquiatr 2002; 60:138-141.

9. Koch TK, Schmidt KA, Wagstaff JE, Ng WG, Packman S. Neurologic complications in galactosemia. Pediatr Neurol 1992;8:217-220.

10. Casella EB, Martins FRP, Miura IK, Vieira MA, Porta G. Deficiência da 3-OH-3-Metil-Glutaril-Coa-Liase como causa de coma no período neonatal. Arq Neuropsiquiatr 1998; 56:472-475.

11. Palmini A, Gambardella A, Andermann F, Dubeau F, da Costa JC, Olivier A. Usefulness of focal rhythmic discharges on scalp EEG of patients with focal cortical dysplasia and intractable epilepsy. Electroencephalogr Clin Neurophysiol 1996;98:243-249.

12. Palmini A, Gambardella A, Andermann F, et al. Intrinsic epileptogenicity of human dysplastic cortex as suggested by corticography and surgical results. Ann Neurol 1995;37:476-487.

13. Barkovich JA. Normal development of the neonatal and infant brain, skull, and spine. In Barkovich JA, ed. Pediatric Neuroimaging. 3.Ed. Philadelphia: Lippincott Williams \& Wilkins, 2000;13-71.

14. Porter BE, Brooks-Kayal A, Golden JA. Disorders of cortical development and epilepsy. Arch Neurol 2002;59:361-365. 